\title{
Data, Digital and Development: 4차 산업혁명 패러다임에 따른 주요 원조기관들의 대응 동향
}

목차

I. 서론 : 국제사회에 던져진 두 가지 화두

II. 4차 산업혁명 패러다임과 국제개발협력

1. 4차 산업혁명 개념의 한계

2. 4차 산업혁명 패러다임

3. 데이터와 디지털

4. 개발도상국의 위기와 기회

III. 원조기관들의 대응 동향

1. 영국 DFID: Development in a Digital World

2. 미국 USAID: Digital Development

3. $\mathrm{KOICA}$ 의 현황

IV. 결론

참고 문헌 


\section{요 약}

4차 산업혁명은 지속가능발전목표(Sustainable Development Goals, SDGs)와 함께 국제사회에 던져진 중요한 화두다. 4차 산업혁명의 개념이 다소 모호한 측면이 있으며, 특히 한국에서 집중적으로 다루어지는 측면이 있으므로 객관성을 확보하기 위해서는 국제 사회의 보편적인 접근 방식을 검토할 필요가 있다. 그럼에도 불구하고 4차 산업혁명은 미래에 대한 예측이라는 점에서 분명한 의의를 지닌다. 기술 변화와 미래 사회변동에 대해 접근하는 방식은 국가별로 상이하게 나타나지만 중요한 기술에 대한 인식은 공통된 측면이 있으며, 4 차 산업혁명에 관련된 기술들은 대부분의 국가에서 중요하게 생각하는 기술이다. 따라서 4 차 산업혁명의 개념이 국제적으로 합의된 개념이 아니라고 하더라도, 그러한 개념이 함축하고 있는 패러다임은 검토될 필요가 있다.

4차 산업혁명의 패러다임과 관련된 기술에서, 핵심 요소는 데이터와 디지털이라는 키워드로 정리할 수 있다. 데이터와 디지털은 최근에 대두된 개념은 아니다. 마찬가지로, 4차 산업혁명이 완전히 새로운 기술들을 다루고 있는 것도 아니다. 여기에 관련된 기술들은 지속적으로 발전되어 오던 것들이다. 국제개발협력에서도 데이터와 디지털은 중요한 요소다. 영국국제개발부(The Department for International Development, DFID)와 미국국제개발처(United States Agency for International Development, USAID)는 기관 자체의 디지털 전략을 가지고, 기관 내부의 전환을 추구하는 동시에 자체 개발협력 프로그램에 이러한 요소를 적극 반영하려는 노력을 하고 있다.

4차 산업혁명이 이슈가 되고 있는 시기에, 이러한 국제적 동향이 개발협력 관련 기관에 주는 시사점은 몇 가지로 요약할 수 있다. 첫째, 기관 내부의 디지털 역량 강화의 필요성 이다. 둘째, 수원국의 데이터 관리 역량, 디지털 기술 활용 역량을 강화하는 것을 모든 사업에 걸쳐 주류화하는 것이다. 마지막으로, 기술의 발전이 미래 개발도상국 사회에 미칠 수 있는 부정적인 요소들에 대해 사전에 논의하고 적절한 대응 방안을 마련하는 것이다.

주제어 : 4차 산업혁명, 데이터, 디지털, 국제개발협력 


\section{I. 서론 : 국제사회에 던져진 두 가지 화두}

2016년 1월은 세계사에서 매우 중요한 시기로 기록될 것 같다. 두 개의 커다란 화두가 국제사회에

던져졌기 때문이다. 먼저 지속가능발전목표(Sustainable Development Goals, 이하 SDGs)의 시대가 시작되었다. 그리고 1월 20일부터 23일까지 스위스의 다보스에서 개최된 제 46 회 세계경제 포럼(World Economic Forum, 이하 WEF)에서 '4차 산업혁명(The fourth industrial revolution)' 이라는 화두가 제시되었다.

두 가지 화두는 포용적 성장과 과학기술혁신의 관계를 다룬다는 공통점을 지닌다. 접근 방식에는 차이가 있다. SDGs는 과학기술혁신이 개발도상국의 성장을 위한 중요한 수단이라고 강조한다 (이상급, 2016). 반면, 4 차 산업혁명의 개념은 기술 발전의 결과로 일자리가 사라지고 양극화가 심해질 수 있다는 예측을 하고 있어, 기술 혁신과 지속 가능한 발전이 모순적 관계에 놓여 있다는 것을 나타낸다.1)

$\mathrm{SDGS}$ 와 4차 산업혁명은 대비되는 속성을 지닌다. SDGs가 비교적 장기간에 걸쳐 다양한 이해 관계자들이 참여하는 논의를 통해 도출된 구체적인 목표인 반면, 4 차 산업혁명은 합의를 통해 도출된 개념으로 보기는 어렵다. SDGs가 공동의 목표이며, 국제사회의 협력과 파트너십을 통한 대응이 지속적으로 강조되는 상황(윤유리, 2017b)인 반면, 4차 산업혁명은 국가 간 경쟁의 영역으로서 경쟁력을 갖추기 위한 독자적인 전략 수립이 강조되고 있다(최병삼·양희태·이제영, 2017). SDGs 가 새천년개발목표(Millennium Development Goals, MDGs)의 후속 목표로 제시되었다는 점에서 주로 개발도상국의 발전과 관련되지만, 4 차 산업혁명은 주로 기술경쟁력을 갖춘 선진국들의 발전과 관련된다.

4차 산업혁명이 선진국의 발전과 깊이 연관되어 있다는 것이, 개발도상국이 4차 산업혁명의 영향으로부터 자유롭다는 것을 뜻하는 것은 아니다. 기술의 수준이 낮고 단순한 공정일수록 자동화의 가능성은 높아진다. 노동이 기계로 대체되는 사례는 우리 주위에서도 어렵지 않게 찾아볼 수 있어, 노동집약적 산업구조를 지닌 개발도상국은 국제무역에서 비교 우위를 상실할 수 있다. 일반적으로 개발도상국의 기술적 - 사회적 대응 능력은 선진국에 비해 낮아 미래에 나타날 변화가 개발도상국에 보다 많은 영향을 미칠 가능성이 있다(윤유리, 2017a).

따라서 국제개발협력의 관점에서 4 차 산업혁명이 개발도상국에 어떤 영향을 미칠 것인지 고민하고, 대응 방안을 찾으려는 노력은 중요하다. SDGs 달성을 위한 방안도 4차 산업혁명으로

1) 김영목. “제4차 산업혁명과 한국의 국제개발협력”. 「매일경제」(2016.01.29. 보도기사) 
인한 미래사회의 변동이라는 조건과 함께 논의될 필요가 있다. 4차 산업혁명이 결과적으로 불평등을 강화시키고 포용적 성장을 저해시킬 가능성이 있는 반면(정민, 2016), SDGs 는 포용적 성장을 강화하는 기제이기 때문이다. 향후 국제개발협력 관련 기관들을 중심으로 4차 산업혁명 으로 제시되는 기술의 발전이 개발도상국 및 국제개발협력 활동에 어떠한 영향을 미치게 될 것인지에 대해 지속적인 관찰과 논의가 지속되어야 할 것이다. 


\section{4차 산업혁명 패러다임과 국제개발협력}

\section{4차 산업혁명 개념의 한계}

제I 장

방식은 국가별로 많은 차이가 있다. 한국은 대통령령으로 '4차산업혁명위원회의 설치 및 운영에 관한 규정'을 공포(2017. 8.)하고, 대통령직속 4차 산업혁명위원회를 설치하여 운영하고 있을 정도로 4 차 산업혁명 대응에 매우 적극적이다. 하지만, 세부 내용에 대해서는 다양한 견해 차이와 논란이 존재하며(김상훈, 2017), 4차 산업혁명은 실체가 없는 정치적 구호에 불과하다는 비판도 지속적으로 제기되고 있다.2)

‘4차 산업혁명’은 다소 한국적 개념이 부가된 측면이 있다. 4차산업혁명위원회는 공식 홈페이지를 통해 제공되는 ${ }^{4} 4$ 차산업혁명 해외정책자료집』에는 미국, 독일, 일본, 중국의 4 차 산업혁명 정책 현황 및 추진 체계가 요약.정리되어 있다. 미국, 일본, 중국을 분석한 자료에서 두드러지는 키워드는 '인공지능(Artificial Intelligence, 이하 AI)'이며, 독일의 경우 '첨단기술전략 2020'과 ‘인더스트리 4.0'3)이 주요 키워드다(4차산업혁명위원회, 2017). 동 위원회가 제시한 타 국가 사례에서 한국처럼 4 차 산업혁명이라는 개념을 정책 용어로 직접 차용한 사례는 나타나지 않는다.

학술적 논의에 있어서도, 4 차 산업혁명은 주로 한국에서 활발히 다루어지는 키워드다. 구글 (Google)이 제공하는 학술검색서비스인 Google Scholar에서 “4차 산업혁명”을 키워드로 검색 하면 약 8,320 여 건의 관련 콘텐츠가 검색된다. 같은 표현을 영어로 옮겨 "4th industrial revolution”으로 검색하면 약 2,220여 건이 검색4)되는 것과는 대조적이다.

한국에서는 2016년 1 월 이후 4 차 산업혁명에 대한 논의가 거의 모든 분야에 걸쳐 지속적으로 이루어지고 있다. 간단한 인터넷 검색만으로도 이러한 사실을 확인할 수 있다. 그것이 '적극적이고 선제적인 대응' 인지 '과잉 대응'인지에 대한 평가는 엇갈릴 수 있지만, 현재 한국에서 중요하게 다루는 주제인 것만은 분명하다. 그러나 4차 산업혁명과 국제개발협력 또는 4차 산업혁명이 개발도상국에 미치는 영향 등에 관한 논의에 있어서는 객관성과 균형이 확보된 관점이 필요하다.

2) 안현실. “4차 산업혁명을 파는 장사꾼들”. 「한국경제 오피니언(2016.11.18.보도기사); 배용진. 2017. “관(官)이 낳은 버블 한국에만 있는 4 차 산업혁명”. 『주간조선』 2509 호. 서울: 조선일보.

3) 독일의 Inudstry 4.0은 ICT와 제조업의 결합이 핵심이며, 프로젝트성 정책의 특성을 지닌다(김상훈, 2017).

4) 검색일 2018. 5. 27. 기준. 
어떤 이슈에 대해 한국적 맥락이 너무 부각되어 다루어질 경우, 국제사회의 보편적 동의를 얻기가 어렵기 때문이다.

\section{4차 산업혁명 패러다임}

4차 산업혁명은 그 개념이 다소 모호한 측면이 있다. 최근 다양한 논의가 이루어지고 있지만 아직까지는 그 본질을 파악하는 것이 제한된다(테크노베이션파트너스, 2016). 하지만 반드시 4차 산업혁명이라는 용어를 전면에 드러내지 않더라도, 국가별로 미래 유망 기술과 제조 부문을 혁신하기 위한 전략의 수립은 여러 선진국과 강소국을 중심으로 활발히 이루어지고 있다(테크노 베이션파트너스, 2016; 김상훈, 2017). 국가별로 기술 변화에 대한 혁신 전략을 수립하는 것은 과거에도 이루어졌으므로 새로운 것은 아니다. 그러나 국가 간 상황에 대한 인식과 대응 방안이 마치 경쟁을 하듯 유사하다는 점은 주목할 필요가 있다. 이는 최근 스타트업(start-up)이나 글로벌 기업이 혁신적인 기술이나 사업 모델을 개발하여 사회에 많은 변화를 가져오는 것을 경험하면서, 앞으로도 이러한 추세가 가속화될 것이라고 전망하는 것과 관련된다고 볼 수 있다 (최병삼·양희태·이제영, 2017).

2016년 WEF가 4차 산업혁명에 대한 논의를 주도하며 제시한 미래 기술은 그 자체가 완전히 새롭거나 혁명적인 것이라고 보기는 어렵다. 당시 $\mathrm{WEF}$ 는 미래사회 변화의 기술적 동인 및 비중으로, 모바일 인터넷과 클라우드 기술(34\%), 빅데이터 분석(26\%), 신에너지 공급 기술(22\%), 사물인터넷(14\%), 크라우드 소싱, 공유경제, 개인 간 거래 플랫폼( $12 \%)$, 로보틱스와 자율주행 (9\%), 인공지능(7\%), 3D 프린팅(6\%), 재료, 생명공학 및 유전학(6\%) 등을 제시하였다(WEF, 2016). 이러한 기술들은 과거로부터 지속적으로 축적되어 온 것으로, 최근에 생겨난 개념이 아니다(이정동, 2017).

따라서 4차 산업혁명을 구체적인 목적이나 개념으로 이해하기보다는 일종의 패러다임으로 접근할 필요가 있다. 최병삼 외(2017)는 "4차 산업혁명에 대한 논의 자체가 무의미하다는 견해도 있으나, 변화를 모색하기 위한 ‘작업가설(working hypothesis)'로서의 의미는 충분”하다고 주장하며, “4차 산업혁명을 이론(theory)보다는 전략(strategy)으로 이해하고, 우리의 현안을 해결하는 ‘한국형 4차 산업혁명 전략'을 찾는 것을 목표로 설정” 해야 한다는 의견을 제시한다. 국제개발협력과 4 차 산업혁명에 관한 논의는 4 차 산업혁명을 하나의 전환적 패러다임으로 간주 하고, 이러한 패러다임하에서 국제개발협력이 어떻게 이루어지고 있는지를 검토하고, 향후 어떻게 대응해 나가야 할 것인지를 고찰하는 과정이 되어야 할 것이다. 


\section{3. 데이터와 디지털}

기술 발전이 미래 사회에 미치는 영향은 $\mathrm{WEF}$ 외에도 다수의 기관에 의해 연구되어 왔다. 김진하 (2016)는 이와 같은 연구 결과를 바탕으로 4차 산업혁명은 주로 정보통신기술((Information and Communications Technologies), 이하 ICT)의 기반에서 이루어질 것으로 예측하고 있다. WEF는 4차 산업혁명이 '사이버물리시스템(Cyber-Physical System, 이하 CPS)'을 기반으로 이루어질 것이라고 설명한다(WEF 윕사이트; 김진하, 2016). CPS는 구성 요소들이 센서 등을 통해 서로 정보를 주고받으며 자동으로 관리 및 통제되는 시스템이라고 설명할 수 있는데, 이러한 시스템도 ICT의 기반 위에서 실현될 수 있다.

4차 산업혁명으로 인한 변화는 모든 것이 연결되는 ‘초연결성’과, 시스템이 빅데이터 분석을

통해 최적의 대안을 스스로 판단하는 '초지능화’로 설명될 수 있다(김진하, 2016). 초연결성은 현실 세계에서 보다 많은 양의 데이터를 확보할 수 있게 하는 조건이다. 초지능화는 그렇게 수집된 데이터를 보다 정교하게 분석할 수 있도록 하는 조건이다. 초연결성을 지닌 사회(현실 세계, physical)에서 확보된 데이터는 인공지능, 클라우드 컴퓨팅 기술을 바탕으로 가상 세계 (cyber)에서 분석이 이루어진다. 그리고 분석 결과는 다시 현실 세계에 적용되는 순환 고리를 갖게 되는데(최병삼·양희태·이제영, 2017), 이것이 바로 사이버-물리시스템의 작동 방식이다.

결국 4차 산업혁명 패러다임에서 새로운 가치는 데이터를 확보하고 분석하며, 활용하는 과정 에서 발생된다고 할 수 있다. 이러한 시스템이 각 산업 분야 또는 공공 서비스에 적용되면 사회의 많은 부분에서 파괴적 혁신이 발생할 것이라고 보는 것이 4 차 산업혁명의 관점이다. $<$ 표 $1>$ 은 주요 국가들의 4 차 산업혁명 관련 정책 현황을 정리한 것이다. 국가별 정책의 초점과 대응 방향에는 차이가 있지만, 핵심 기술은 공통적으로 나타난다는 점에 주목할 필요가 있다. 
〈표 1〉국가별 제4차 산업혁명 정책 현황 비교

\begin{tabular}{|c|c|c|c|c|}
\hline 구분 & 미국 & 독일 & 일본 & 중국 \\
\hline $\begin{array}{l}\text { 주요 } \\
\text { 정부 } \\
\text { 정책 }\end{array}$ & $\begin{array}{l}\text { - NNMI 네트워크 } \\
\text { - NITRD } \\
\text { - 브레인 이니셔티브 }\end{array}$ & $\begin{array}{l}\text { - 하이테크 전략 } 2020 \\
\text { - 인더스트리 } 4.0\end{array}$ & $\begin{array}{l}\text { - 일본재홍전략 } 2015 \\
\text { - 과학기술 이노베이션 } \\
\text { 종합전략 } 2015 \\
\text { - 로봇 신전략 }\end{array}$ & $\begin{array}{l}\text { - 중국제조 } 2025 \\
\text { - 중국 인터넷 플러스 }\end{array}$ \\
\hline $\begin{array}{l}\text { 핵심 } \\
\text { 기술 }\end{array}$ & \multicolumn{4}{|c|}{$\begin{array}{l}\text { - CPS(Cyber-Physical System), 빅데이터, loT(Internet of Things), 인공지능, 로봇공학, 클라 } \\
\text { 우드 등 }\end{array}$} \\
\hline $\begin{array}{l}\text { 주요 } \\
\text { 추진 } \\
\text { 조직 }\end{array}$ & $\begin{array}{l}\text { - 정부기관 } \\
\text { - 글로벌 제조기업 } \\
\text { - 글로벌 IT기업 }\end{array}$ & $\begin{array}{l}\text { - 정부기관 } \\
\text { - 글로벌 제조기업 } \\
\text { - 글로벌 IT기업 }\end{array}$ & $\begin{array}{l}\text { - 정부기관 } \\
\text { - 글로벌 제조기업 }\end{array}$ & - 정부기관 \\
\hline $\begin{array}{l}\text { 대응 } \\
\text { 방향 }\end{array}$ & $\begin{array}{l}\text { - 제조산업 중심으로 제 } \\
\text { 4차 산업혁명 정책방향 } \\
\text { 설계 } \\
\text { - 지국 내 글로벌 } \Pi \text { 기업의 } \\
\text { 적극적 참여 } \\
\text { - 민간 중심 대응전략을 } \\
\text { 적극적으로 지원 }\end{array}$ & $\begin{array}{l}\text { - 제조산업 중심으로 } \\
\text { 제4차 산업혁명 정책 } \\
\text { 방향 설계 } \\
\text { - 자동차, 기계설비 등 } \\
\text { 자국 글로벌 기업을 } \\
\text { 중심으로 추진 } \\
\text { - 국가 차원의 아젠다 } \\
\text { 제시와 함께 민관의 } \\
\text { 활발한 공동 대응 }\end{array}$ & $\begin{array}{l}\text { - 정부 아젠다 중심의 } \\
\text { 대응전략 추진 } \\
\text { - 기존에 강점을 가진 } \\
\text { 로봇기술 중심의 전략 } \\
\text { 수립 }\end{array}$ & $\begin{array}{l}\text { - 정부 중심의 강력한 } \\
\text { 정책 추진 } \\
\text { - 기존 제조산업을 한 } \\
\text { 단계 발전시키는 주요 } \\
\text { 수단으로 ICT 기술을 } \\
\text { 활용 } \\
\text { - 지국 시장규모를 적극 } \\
\text { 활용 }\end{array}$ \\
\hline
\end{tabular}

출처: 정보통신기술진흥센터 (2016)

데이터의 수집과 분석을 위해서는 ICT의 활용이 필수적이다. 그런데 ICT는 구체적으로 지칭 하는 기술 또는 산업이 있다. 반도체나 통신 장비 등 하드웨어의 제조도 ICT의 범주에 속하고, 소프트웨어 개발이나 무형의 통신 기술 개발도 그러하다. 4차 산업혁명을 위해서는 ICT의 발전이 필수적이지만, 4차 산업혁명을 통한 가치를 창출하는 데는 ICT 기술을 활용하는 게 무엇보다 중요하다. 이러한 맥락에서 최병삼 외(2017)는 'ICT'와 '디지털'의 두 단어가 통상 유사하게 활용되는 측면이 있으나, 4차 산업혁명은 ICT에만 국한된 것은 아님을 감안할 때, 4차 산업혁명을 설명하는 개념으로는 '디지털'이 더 적합하다는 견해를 밝히고 있다. 이는 상당히 타당한 접근으로 판단된다.5) 따라서 '데이터'와 '디지털'을 4차 산업혁명에 관련된 기술의 본질을 설명하는 중요한 키워드로 간주할 수 있다.

개발도상국이 선진국과의 기술 격차를 줄여야 하기 때문에 ICT 기술 개발을 추진하는 것은 중요하지만, 선진국과 경쟁을 하는 것은 사실상 불가능하다. 전술했듯, 4 차 산업혁명으로 포장 된 기술들이 과거로부터 축적되어 온 결과이기 때문에(이정동, 2017), 개발도상국이 기술 추격을 하는 것은 결코 쉬운 일이 아니다.

5) ‘디지털화(digitalization)'라는 표현은 통용되나, 'ICT화’라는 표현은 통용되지 않는다. 디지털은 어떤 대상의 속성에 해당하는 반면, ICT는 기술을 지칭하기 때문이다. 예를 들어, 수기로 작성되어 있는 문서를 ‘디지털화 한다'고 표현하는 것은 일반적이지만, 'ICT화 한다'고 표현하는 것은 그렇지 않다. 


\section{4. 개발도상국의 위기와 기회}

일반적으로 $\mathrm{AI}$ 등 4 차 산업혁명 관련 기술을 선도하는 국가와 추격하는 국가 간 기술 격차는 지속적으로 확대되는 것으로 인식된다(이정원 - 문형돈, 2018). 4차 산업혁명 시대에는 개발도상국과 선진국 간의 기술 격차가 더욱 확대될 것임을 유추할 수 있다. 그럼에도 불구하고 기술 격차를 줄이기 위해 노력하는 것은 필요하겠지만, 과거처럼 개발도상국이 상대적으로 낮은 임금을 비교 우위 삼아 선진국과 협력하거나 경쟁하기는 갈수록 어려워질 것이다. 이러한 측면은 4차 산업혁명 시대에 개발도상국이 맞닥뜨리게 되는 위기라고 할 수 있다.

\section{제I 장}

그렇지만 다른 한편으로는 기회도 있다. 부가가치 창출의 원천이 제조설비 같은 물리적인 인프라 에서 점차 데이터, 네트워크 등 무형의 자산으로 전환되는 것은 물적 자본이 상대적으로 부족한 개발도상국에게 유리한 조건이 될 수 있다. 복제가 용이하다는 디지털의 속성과 초연결성 사회라는 맥락을 감안하면, 개발도상국은 선진국에서 개발되고 검증된 여러 가지 비즈니스 프로세스 또는 서비스 모형을 어렵지 않게 내재화할 수 있을 것으로 예측된다.

기술 도약(leapfrogging)에 유리한 환경이 조성된다는 것도 개발도상국에게는 기회로 작용 할 수 있다. 4차 산업혁명으로 인해 기존 산업의 구조 및 경영 방식에 많은 변화가 발생할 것으로 예측되는데(정보통신기술센터, 2016), 이러한 과정에서 선진국 기업들이 보유하고 있는 설비가 불필요하거나 경쟁력이 낮은 생산요소가 될 가능성이 있다. 혁신을 위해서는 과감히 과거의 자산을 포기할 필요가 있지만, 새로운 투자의 결과를 확신할 수 없는 상황에서 기업이 기존의 설비나 자산, 업무 절차 등을 모두 포기하는 결정을 내리기는 쉽지 않다(존 하겔, 2016). 개발도상국 기업 중 기술 추격의 과정에 있는 기업이 있다면, 과거의 유산에 얽매이지 않을 수 있기 때문에 이러한 상황이 유리하게 작용하여 기술 도약을 달성할 가능성이 높아진다(이근, 2005).

4차 산업혁명 시대의 국제개발협력은 개발도상국의 대응 역량, 즉 데이터의 활용과 디지털 기술의 적용에 관한 역량을 높여 주는 방향으로 이루어질 필요가 있다. 대부분의 선진국에서는 이미 데이터와 디지털이 일상화되어 있다. 개발도상국이 4차 산업혁명 대응 역량을 갖추기 위해서는 중요한 것이 많겠지만, 무엇보다도 이러한 근본적인 체질의 변화가 필요하다. 이것은 단일 사업을 통해 달성할 수 있는 것이라기보다는, 모든 개발협력 활동에서 고려되어야 할 요소라고 생각된다. 이를 위해서는 국제개발협력의 패러다임도 데이터와 디지털을 기본 요소로 간주하는 방향으로 전환될 필요가 있다. 


\section{III. 원조기관들의 대응 동향}

데이터 기반으로 사고하고 또 디지털 기술을 국제개발협력에 적극적으로 도입하자는 주장은 새로운 것이 아닌, 이미 적용되고 있는 중이다. 국제연합(United Nations, 이하 UN) 산하기구인 UN Global Pulse는 '개발 및 인도주의적 목적을 위한 데이터 활용'을 모토로 가지고 있으며, 데이터와 디지털을 주제로 다룬 개발협력 관련 논의 결과는 어렵지 않게 찾아볼 수 있다.

중요한 것은 데이터와 디지털의 적용이라는 이슈가 실제 국제개발협력에서 어떻게 이루어지고 있는지에 관한 것이다. 본 장에서는 영국국제개발부(The Department for International Development, 이하 DFID)와 미국국제개발처(United States Agency for International Development, 이하 USAID)의 사례를 중심으로, 주요 원조기관들이 데이터와 디지털이라는 이슈에 어떻게 대응하고 있는지를 검토하고자 한다.

\section{1. 영국 DFID: Development in a Digital World}

영국 $\mathrm{DFID}$ 는 디지털에 관련된 별도의 전략을 가지고 있다. $\mathrm{DFID}$ 는 2012년 12 월, ' $\mathrm{DFID}$ Digital Strategy 2012-2015'를 수립하였으며, 이후 2018년 1월에 새로운 버전의 디지털 전략인 'Digital Strategy 2018-2020: Doing Development in a Digital World'를 발표하였다.

$\mathrm{DFID}$ 는 2012년에 발표된 디지털 전략에서 '디지털' 의 개념을 '인터넷을 통해 전달되는 콘텐츠 또는 커뮤니케이션' 으로 설정하며, 이 전략 자체는 '이해관계자 및 수혜자들과 소통하는 방식' 으로 규정하고 있다(DFD, 2012). 디지털에 대한 $\mathrm{DFD}$ 의 접근 방식은 크게 세 가지로 정리된다. 먼저 네트워크를 확장하는 것이다. 이것은 더 많은 사람으로부터 $\mathrm{DFID}$ 가 추진하는 원조 사업에 대한 모니터링과 피드백을 받는 것을 의미한다. 두 번째는 프로그램의 기획과 운영 단계에 디지털을 활용하는 것으로, 특히 조달이나 송금 등을 디지털 기반으로 추진하는 것을 의미한다. 세 번째는 보다 효율적이고 투명한 의사소통을 지향하는 것이다. 디지털은 빠른 의사소통을 가능하게 하는 수단이며, 각종 정보와 데이터를 투명하게 공개할 수 있게 함으로써 신뢰 구축에 기여할 수 있다(DFID, 2012).

이 전략에서 제시하는 활동의 영역은 크게 세 가지로 구분될 수 있다. 먼저, 첫 번째 영역으로 정보활동(information activities)이 있다. 이는 $\mathrm{DFID}$ 의 활동을 알리는 데 있어 소셜미디어를 보다 적극적으로 활용하거나, 사업기획에 데이터를 활용하거나, 일반인들의 질의응답을 처리할 때 절차를 개선한다거나 하는 활동을 포함한다. 또 모니터링 및 평가 $(\mathrm{M} \& \mathrm{E})$ 와 관련된 활동이 
있다. 현재 추진 중인 프로그램에 대한 피드백을 보다 적절히 모으는 활동이나, 추진 현황을 실시간으로 추적할 수 있게 하는 활동들이 여기에 속한다. 두 번째 영역은 거래 서비스 (transactional services)에 관한 것이다. 거래 서비스에는 조달, 계약, 펀딩, 장학금, 채용 등이 있으며, 과거 식민시대 식민지 공무원들에 대한 연금 지급에 관한 내용까지도 포함된다. 세 번째 영역은 조직 내부의 역량 강화(organisational capability)에 관련된 활동이다. 여기에는 $\mathrm{DFID}$ 구성원들이 디지털 도구들을 보다 효율적으로 사용할 수 있도록 교육하고 훈련하는 내용이 포함된다(DFID, 2012).

$\mathrm{DFID}$ 의 첫 번째 디지털 전략은 공적개발원조(Official Development Assistance, 이하 ODA) 사업에 디지털 요소를 어떻게 반영하고 활용할 것인가에 대한 내용이라기보다 내부의 업무 절차를 효율적으로 개선하고, 외부와의 소통을 보다 투명하게 처리하기 위한 지침에 가까운 것으로 평가된다. 물론 전략 문서의 곳곳에서 디지털 요소가 $\mathrm{DFDD}$ 의 프로그램 효과를 높이는 데 기여 할 수 있다는 내용이 나타난다. 하지만 이러한 내용이 디지털을 활용한 사업을 발굴해야 한다거나, 각 섹터별 사업에 디지털 요소를 적극적으로 반영하자는 것은 아니다. 모니터링 및 평가(M\&E), 사업 홍보 또는 커뮤니케이션에 디지털 요소를 활용한다는 의미에 가깝다고 볼 수 있다.

$\mathrm{DFID}$ 가 디지털이라는 주제로 별도의 전략을 수립했다는 것은, $\mathrm{DFID}$ 가 디지털을 중요한 요소로 고려하고 있음을 보여 준다는 점에서 의의를 지닌다. 그렇지만 인터넷 기반으로 내부 업무를 처리하거나, 소통을 강화하는 것이 아주 참신한 내용이라고 보기는 어렵다. 웬만한 선진국 에서 활동하는 기관이라면 정도의 차이는 있겠지만 이미 대부분 적용하고 있는 내용이라고 볼 수 있기 때문이다. $\mathrm{DFD}$ 의 첫 번째 디지털 전략은 자신들의 사업에 명확한 특성을 부여하거나 디지털을 주류화(mainstreaming)하기 위한 선언이라기보다는, 영국 정부 차원의 디지털 전략6)을 기관 차원으로 반영시키기 위한 전략 문서로 이해하는 것이 적절하다.

DFID가 2018년에 내놓은 새로운 디지털 전략인 “Digital Strategy 2018-2020: Doing Development in a Digital World”는 그 제목에서 유추할 수 있는 것처럼 디지털을 개발협력 사업에 보다 적극적으로 적용하고자 하는 내용이 포함되어 있다. 이는 2012년에 내놓은 전략에서 한 단계 진보한 것으로 볼 수 있다. 새로운 전략은 두 가지 영역에서 디지털 기술 활용에 대해 접근할 것을 명시하고 있다. 우선, 개발도상국을 위한 프로그램 효과를 높이기 위한 디지털 기술의 활용 영역(Doing development in a digital world)이 있다. 그리고 다른 하나는 이전 버전과 연장선상에 있는 내용으로, $\mathrm{DFID}$ 의 커뮤니케이션이나 내부 업무 절차에 디지털 기술을

6) 2009년 영국 정부는 디지털 지식경제시대를 주도하기 위한 대응 전략을 담은 정책 문서인 ‘Digital Britain’을 발표하였다. 동 정책 문서에는 정보통신 기반을 확충하고, 이를 토대로 정치와 민주주의, 경제, 공공서비스 등을 개선시키기 위한 방안들이 제시되어 있다(TSO, 2009). 
활용하여 투명성과 효율성을 높이는 것과 관련된 영역(Transforming as a digital department) 이다(DFID, 2018).

〈표 2〉 DFID Digital Strategy 2018-2022의 주요 내용

\begin{tabular}{|c|c|c|}
\hline 영역 & 중점요소 & 주요 활동 \\
\hline \multirow{10}{*}{$\begin{array}{l}\text { I. 디지털 } \\
\text { 세계에서의 } \\
\text { 개발 활동 } \\
\text { (Doing } \\
\text { development } \\
\text { in a digital } \\
\text { world) }\end{array}$} & \multirow{4}{*}{$\begin{array}{l}\text { I.1. 디지털 기술의 } \\
\text { 영향을 극대화 } \\
\text { 시킬 수 있는 } \\
\text { 환경 조성 }\end{array}$} & I.1.1. 디지털 개발을 위한 전략적 파트너십 구축 \\
\hline & & I.1.2. 타 정부기관과의 협업 \\
\hline & & I.1.3. 개발도상국 역량 강화 및 기술 지원 \\
\hline & & I.1.4. 디지털 관련 국제적 정책 논의에 적극 참여 \\
\hline & \multirow{3}{*}{$\begin{array}{l}\text { I.2. 검증된 디지털 } \\
\text { 모델의 공유 및 } \\
\text { 확산 }\end{array}$} & I.2.1. 효과적 솔루션에 대한 확산 \\
\hline & & I.2.2. 효과적이고 지속 가능한 디지털 프로그램 개발 \\
\hline & & I.2.3. 새로운 사업 모형('Digital Trailblazers')의 검증 \\
\hline & \multirow{3}{*}{$\begin{array}{l}\text { I.3. 성과 사례의 } \\
\text { 시스템화 및 } \\
\text { 표준화 }\end{array}$} & I.3.1. 지식의 통합, 조정, 공유('Digital Grid’7) 구축) \\
\hline & & I.3.2. 디지털 기술에 대한 인식 제고, 역량 강화 및 품질관리 \\
\hline & & I.3.3. 지역, 섹터 등 맥락을 고려한 지식과 가이드라인 제공 \\
\hline \multirow{10}{*}{$\begin{array}{l}\text { II. 디지털 기관 } \\
\text { 으로 전환 } \\
\text { (Transforming } \\
\text { as a digital } \\
\text { department) }\end{array}$} & \multirow{3}{*}{ II.1. 서비스 디자인 } & l.1.1. '디지털 전환(Digital Transformation)'의 지속 \\
\hline & & II.1.2. 클라우드 호스팅 \\
\hline & & II.1.3. 사이버 보안 \\
\hline & \multirow{4}{*}{$\begin{array}{l}\text { II.2. 플랫폼과 기술 } \\
\text { 공유 }\end{array}$} & II.2.1. 'Aid Management Platform'을 범정부적으로 공유 \\
\hline & & II.2.2. Common Technology Services8)의 국제적 적용 \\
\hline & & II.2.3. GOV.UK에 업로드되어 있는 과거 콘텐츠의 재편 \\
\hline & & II.2.4. 국외에서 사용하는 통신·데이터 네트워크의 성능 개선 \\
\hline & \multirow{3}{*}{$\begin{array}{l}\text { 11.3. 데이터의 } \\
\text { 가용성, 품질, } \\
\text { 활용 }\end{array}$} & II.3.1. 국가별 데이터 시스템 강화 지원 \\
\hline & & II.3.2. 데이터 기반 사업기획, 모니터링, 평가 및 의사 결정 \\
\hline & & II.3.3. 책무성과 투명성 강화를 위한 데이터의 공개 \\
\hline
\end{tabular}

출처: DFID (2012) 내용을 바탕으로 저자 재구성

<표 1>은 $\mathrm{DFID}$ 의 새로운 디지털 전략의 주요 내용을 정리한 것이다. 2018년 버전은 이전 버전에 비해 보다 구조화되었으며, 실행 방안에 대해서도 구체적이고 상세하게 제시하고 있다. 새 전략은 이전 전략과 마찬가지로 영국 정부 차원의 관련 정책에 연계하여 작성된 측면도 있지만, 디지털 기술을 기관의 고유 미션인 개발도상국 대상 프로그램의 기획과 실행 과정에 어떻게 활용할 것인지에 대한 방안을 구체적으로 제시하고 있다는 점에서 이전 버전의 전략과 구분된다. 새 전략 수립의 의의는 바로 여기에 있다.

7) DFID에서 추진한 디지털 프로그램에 대한 사례를 공유하기 위한 지식 플랫폼으로 2018년 1월 베타테스트를 거친 것으로 알려지며, 아직 본격적인 서비스를 시작하지는 않은 것으로 보인다.

8) 영국 정부 내부에서 활용되는 업무 관련 시스템 구축, 기술 적용 등에 관한 서비스를 칭하는 것으로, 별도의 담당 부서인 Common Technology Service팀이 존재한다. 


\section{2. 미국 USAID: Digital Development}

미국 USAID는 디지털 기술 및 데이터 이슈에 관한 전담 조직인 '디지털 개발센터(Center for Digital Development, 이하 CDD)'를 가지고 있다. CDD는 USAID의 'U.S. Global Development Lab'을 구성하는 하나의 조직인데, 2010년에 작은 규모로 시작된 '모바일 머니 (mobile money)'팀이 현재의 CDD로 이어졌다(USAID, 2017).

$\mathrm{CDD}$ 의 고유 미션은 $\mathrm{USAID}$ 내부에서 디지털 기술의 효과적 활용, 데이터 분석에 관한 자문을 담당하는 것이다. 동시에 개발도상국의 모바일, 디지털 기술의 접근성을 개선하는 방안을 연구 하고, 새로운 기술의 적용하는 데 필요한 여러 논의를 주도하기도 한다( USAID, 2017). 다시 말해, $\mathrm{CDD}$ 는 $\mathrm{USAID}$ 내부에서 디지털 기술과 데이터 분석의 활용을 주류화하는 역할을 담당 하는 조직으로서 대표성을 갖는다.

$\mathrm{CDD}$ 의 전략은 크게 다섯 가지 영역에 초점이 맞춰져 있다. 여기에는 디지털 포용(Digital Inclusion), 디지털 금융(Digital Finance), 개발정보학(Digital Informatics), 지리공간센터 (The GeoCenter) 그리고 미국 정부의 글로벌 식량안보 이니셔티브인 'Feed the Future'9)를 뒷받침하기 위한 'Feed the Future를 위한 디지털 개발(Digital Development for Feed the Future, 이하 D2FTF)'이 있다(USAID, 2017).

첫 번째로, 디지털 포용은 정보 격차(digital divide)를 극복하기 위한 영역이다. $\mathrm{CDD}$ 는 지난 10 년간 디지털 기술의 유례없는 확산이 이루어졌지만 여전히 전 세계 $55 \%$ 에 해당하는 40억 명 이상의 인구가 아직도 인터넷에 접근하지 못하고 있는 상황을 지적하며, 이러한 정보 격차를 개발도상국의 경제·사회개발을 저해하는 원인으로 지목한다(USAID, 2017).

두 번째로 디지털 금융은 금융 포용을 실현하기 위한 접근이며, 금융거래 비용을 낮춰 저소득층의 금융 접근성을 개선한다(USAID, 2017). 간혹 개발도상국에서의 금융 포용이 소액 대출(microcredit)과 같은 것으로 인식되는 경향도 있는데, 좀 더 넓은 의미로 볼 때 금융 포용은 개발도상국의 저소득층이 계좌를 개설하고 송금을 하는 등 일반적 금융 서비스에 있어 접근성 개선의 의미로 이해하는 것이 보다 적절하다(임한나, 2018). $\mathrm{CDD}$ 는 디지털 금융이 금융 접근성의 개선을 통해 거버넌스(governance), 부패 감소 등도 함께 달성할 수 있을 것으로 보고 있다. 또 전기, 깨끗한 물, 저렴한 건강보험 등 주민들 삶의 질을 향상시킬 수 있는 여러 가지 비즈니스 모델의

9) 동 이니셔티브는 글로벌 기아 및 빈곤 감소가 목적이며, 오바마 대통령의 주도로 2010년에 론칭되었다. 여러 정부부처 및 관련 기관이 참여하는 정부 통합형(whole of government)으로 추진된다는 특징이 있으며, USAID가 총괄한다 (이효정, 2014). 
파생도 가능할 것으로 본다(USAID, 2017).

세 번째로, 개발정보학은 개발협력사업에 있어 데이터를 활용하는 것을 의미한다. 개발협력 프로그램의 기획, 집행, 평가 등의 단계에 적절하고 정확한 데이터를 사용하는 것은 사업의 효과를 높이는 데 기여할 수 있다(USAID, 2017). CDD의 활동은 축적된 데이터를 사업 기획, 평가 등에 활용하는 것에만 국한되지 않는다. 협력 국가에 정보화 시스템의 구축이나 정부 관료들의 데이터 분석 역량 강화를 지원하기도 한다. USAID는 특히 보건 분야에서 데이터 시스템 구축을 지원하는 다양한 프로그램이 있으며, 이와 관련하여 한국국제협력단(Korea International Cooperation Agency, 이하 KOICA)과 협력했던 사례도 존재한다. $\mathrm{KOICA}$ 가 가나에서 추진하고 있는 '가나 볼타지역 모자보건 개선사업'은 업무 담당자가 지역 보건 정보를 수기로 작성한 후 온라인에 일일이 입력하던 방식에서 태블릿 $\mathrm{PC}$ 를 활용하는 방식으로 개선하는 것을 지원하고 있다. 이로써 데이터 관리의 비효율성을 개선하고 데이터의 정확성을 높일 수 있다. KOICA는 이 사업을 추진하면서 USAID와 협력하고 있는데, 이 사업이 가나의 정보 시스템을 개선한다는 점에서 $\mathrm{CDD}$ 의 전략에 매우 부합하는 사업으로 볼 수 있다.

네 번째로, 지리정보 관련 업무를 담당하는 GeoCenter는 각종 지리정보, 생물정보, 위성사진, 맵핑 도구 등을 활용하여 공간정보 데이터를 구축하고 분석하여, 이를 개발협력 프로그램의 기획이나 모니터링 등에 활용하도록 돕는다. 이러한 목적을 달성하기 위해 GeoCenter는 USAID 조직 내 구성원들에게 관련 지식을 전수하기도 하고, 협력 국가별 상황을 분석하여 프로그램 기획 방향을 제시하기도 한다. 동시에 개발도상국이 위성 정보를 활용하여 재해 및 재난 대응, 생물 다양성의 보존, 토지 또는 산림 관리 등에 활용할 수 있도록 지원하기도 한다. 지리정보를 구축하기 위한 방법으로는 'Youthmappers Network'를 조직하여 활용하기도 하는데, 이 네트워크는 30 개 국가에서 100 여 개의 대학에 소속된 5 천여 명의 대학생들이 참여하며, 인도주의 목적으로 활용한다는 전제하에 지리공간 데이터를 생성하는 역할을 담당한다(USAID, 2017).

마지막으로, D2FTF는 미국 정부의 글로벌 식량안보 이니셔티브인 'Feed the Future'를 디지털 개발의 관점으로 접근하는 것이다. $\mathrm{D} 2 \mathrm{FTF}$ 는 휴대전화, 센서, 데이터 수집 및 관리 시스템 등 여러 가지 디지털 기술을 활용하여 농업 생산성을 향상시키는 솔루션을 발굴하고 확산한다. 솔루션의 발굴 방식인 D2FTF는 USAID의 개발혁신벤처(Development Innovation Ventures, 이하 DIV) 프로그램을 통해 기업을 발굴·육성하기도 하고, '데이터 주도형 농업경진 대회(Data-driven farming prize)'10)를 개최하여 해당 지역의 자연·사회적 맥락에 부합하는

10) 2017년에 론칭되었으며, 추진 사례로 네팔에서 진행되었던 '네팔 데이터 주도형 농업 경진대회(Data-Driven 
솔루션을 찾기도 한다(USAID, 2017).

<표 2>는 USAID의 디지털 개발 전략의 5 대 중점 영역과 각 영역이 추구하는 내용에 대해 정리한 것이다. 한편 이러한 중점 영역의 추진을 위한 접근법으로, USAID는 크게 세 가지를 제시하고 있다. 먼저, '포용적 디지털 경제의 촉진(Catalyzing Inclusive Digital Economies)'이 있다. 이는 민·관 협력 파트너십 등 다양한 제휴를 통해 재원을 동원하여 개발도상국의 인터넷 접근, 디지털 결제 등에 관한 인프라 개선을 추진하는 것이다. 둘째, '조직 내부 역량 강화 (Building Agency Capacity)'가 있다. 이는 디지털 기술, 데이터와 지리정보 분석 등을 개발 협력 프로그램에 접목시키기 위한 목적으로, 내부 구성원들에게 관련된 교육훈련을 추진하는 것이다. 셋째, 'USAID 프로그램의 가속화(Accelerating USAID Programming)' 가 있다. USAID는 약 2010년부터 시장주도형 혁신을 추구하며, 디지털 기술과 여러 데이터를 내부 전략 및 개발협력 프로그램의 기획에 활용하여 왔는데, 제시된 세 번째 접근법은 이러한 측면을 더욱 강화하는 것을 의미한다(USAID, 2017).

\section{〈표 3〉 USAID의 디지털 개발 전략(Digital Development Strategy)의 주요 내용}

\begin{tabular}{|c|c|}
\hline 중점 영역 & 목적 및 추진 내용 \\
\hline $\begin{array}{c}\text { 디지털 포용 } \\
\text { (Digital Inclusion) }\end{array}$ & 정보 격차 극복, 인터넷 접근성 개선 \\
\hline $\begin{array}{c}\text { 디지털 금융 } \\
\text { (Digital Finance) }\end{array}$ & 금융 접근성 개선, 금융을 통해 새로운 비즈니스 모델 개발 \\
\hline $\begin{array}{c}\text { 개발정보학 } \\
\text { (Digital Informatics) }\end{array}$ & 데이터 기반의 사업 추진, 개발도상국 정부의 데이터 역량 강화 \\
\hline $\begin{array}{l}\text { 지리공간센터 } \\
\text { (The GeoCenter) }\end{array}$ & $\begin{array}{l}\text { 지리공간정보 활용을 통한 수요분석, 개발도상국의 지리공간 데이터 활용 } \\
\text { 접근성 개선 }\end{array}$ \\
\hline $\begin{array}{l}\text { FTF를 위한 디지털개발 } \\
\text { (Digital Development } \\
\text { for Feed the Future) }\end{array}$ & 농업생산성 향상을 위한 디지털 기술 솔루션 발굴 및 확산 추진 \\
\hline
\end{tabular}

출처: USAID (2017)를 바탕으로 저자 재구성

$\mathrm{USAID}$ 의 전략은 선언적 수준에 그치지 않고 구체적인 실행 방안 및 현황들을 함께 제시하고 있다는 특징을 지닌다. 전략 체계에서 흔히 볼 수 있는 최종 목표, 비전, 미션 등의 구조는 차용하지 않지만, 현재 추진 중인 각종 개발 프로그램 사례가 함께 제시되고 있어 실행 계획은 매우 구체적 이고 또 추진 방향은 분명하다. USAID의 디지털 개발 전략 또한 $\mathrm{DFID}$ 의 전략과 마찬가지로 디지털 기술을 내부적으로 적용하는 차원과, 외부를 대상으로 적용하는 차원이 함께 다루어지고 있다.

Farming Prize)'가 있다. 


\section{KOICA의 현황}

$\mathrm{KOICA}$ 는 앞서 살펴본 두 기관처럼 데이터와 디지털 기술에 대한 내용을 다루는 전략을 가지고 있지 않다. 관련된 전략으로 'KOICA 과학기술혁신 중장기 전략(2016-2020)'이 있지만, 여기서는 데이터와 디지털을 집중적으로 다루지는 않고 있다. 2016년부터 전자정부 구축사업의 추진에 활용되고 있는 '개도국 전자정부 역량진단 툴킷'은 전자정부 사업이 수원국의 데이터 활용 역량강화를 지원한다는 점에서 데이터 및 디지털로 대변되는 4차 산업혁명 기술과 관련되어 있다고 볼 수 있다. 그러나 특정 분야의 사업에만 국한되어 활용될 수 있다는 한계가 있다.

$\mathrm{KOICA}$ 는 ICT를 범분야로 간주하고 있으며, $\mathrm{KOICA}$ 가 자체적으로 수립한 ICT 마커를 통해 사업들을 분류하고 있다. 별도의 정책 마커를 활용하고 있다는 것은 긍정적이다. 그러나 동 마커의 정의와 기준은 $\mathrm{MDGs}$ 체제에 맞춰 설정된 것으로, SDGs 체제에 부합하는 기준으로 업데이트가 필요하다. 또 동 마커는 수원국의 ICT 역량 강화에 얼마나 기여했느냐를 중심으로 부여된다는 한계가 있다. 동 마커의 입력 기준에 따르면 ICT 산업을 육성하거나, 관련 교육을 수행하거나, 인프라 구축을 지원하는 사업들만 마커 점수를 부여받을 수 있다. 앞서 II장 3절에서 다루었던 것과 같이 농업이나 교육, 보건 등 타 분야 사업에 ICT가 활용되고 있는 경우에 마커 점수가 부여될 수 있다면, 앞서 살펴본 두 기관의 디지털 개발 개념과 유사한 맥락을 지닌 도구로 발전할 수 있다. 만약, KOICA ICT 마커를 'KOICA 디지털 마커'로 재편하고, 국내 개발협력 수행기관들과 공유하여 공통의 성과를 집계할 수 있다면 보다 유의미한 자료를 확보할 수 있게 될 것이다.

$\mathrm{KOICA}$ 가 디지털 개발의 관점에서 새로운 개발협력 솔루션을 찾는 방법은 2015년부터 시작 된 ‘Creative Technology Solution(CTS) 프로그램’이 대표적이다. CTS 프로그램은 초기 기획 단계에서 USAID의 U.S. Global Develoment Lab과 Development Innovation Ventures의 모델을 참조하였다. 또한 정식 운영을 시작한 이후 지속적으로 USAID 및 관련 기관들과 파트너십을 형성하며 교류하고 있어, 선진 공여기관의 사업 모델과 매우 유사한 형태로 추진되고 있다. 


\section{IV. 결론}

지금까지 국제개발협력의 관점에서 4차 산업혁명 패러다임을 검토하고, 이와 관련된 선진

원조기관들의 전략을 분석하였다. 4 차 산업혁명으로 인한 변화는 개발도상국에게 위기이자 기회로 작용할 수 있다. 개발도상국이 시대 변화에 적절히 대응하기 위해서는 관련된 역량의 강화가 필요하다. 여기서는 이러한 역량의 핵심을 데이터를 수집하고 분석하는 역량 그리고 디지털 기술을 활용할 수 있는 역량으로 정의하였다.

국제개발협력에서 데이터와 디지털을 적극 활용하자는 주장은 새로운 것이 아니다. 그런데 이것은

4 차 산업혁명도 마찬가지다. 인공지능은 알파고의 출현으로 인해 최근 들어 더욱 주목받고 있지만, 인공지능이라는 개념은 1950 년대에 이미 시작되었으며, 4차 산업혁명에 관련된 여러 가지 기술도 결국은 지속적인 혁신의 결과로 보는 것이 적절하다(이정동, 2017).

$\mathrm{DFID}$ 와 USAID의 사례도 마찬가지다. 데이터와 디지털에 관련된 두 기관의 전략은 4차 산업혁명 패러다임이 나타나기 전부터 수립되어 있었다. 그럼에도 불구하고 두 기관의 사례를 4 차 산업혁명 패러다임에 대한 대응동향으로 간주하고 분석한 이유는, 두 기관의 전략이 4차 산업혁명 패러다임에서 중요하게 다루어지고 있는 데이터와 디지털 기술을 다루고 있기 때문에, 본질적으로 두 가지는 같은 것으로 간주할 수 있다고 판단했던 것이다.

새롭지 않은 것을 새로운 것처럼 접근하게 되면 오류가 발생할 수 있다. 4차 산업혁명은 기술의 발전으로 인한 미래 사회의 변화를 예측하고 대응하는 데 있어서 중요한 패러다임이 될 수 있다. 그러나 그 내용이 완전히 새로운 것이라고 보기는 어렵다. 따라서 4 차 산업혁명 패러다임에 대한 대응도 이와 같은 맥락에서 이루어질 필요가 있다. 국제개발협력을 수행하는 기관이라면, 지금까지 진행했던 사업들 중에 4차 산업혁명과 본질적으로 연계되는 활동이 어떠한 것인지를 정교하게 분석하는 것부터 시작하고, 그 다음으로는 어떠한 단계를 거칠 것인지를 정립해 나가야 한다.

개발협력에 관련된 담론을 바라보는 실무자의 관점과 고민은 대개 명확하다. 그래서 이것을 어떻게 실현시켜야 하느냐에 관한 것이다. 4차 산업혁명이라는 이슈 그리고 그것에 관련된 선진 기관들의 대응 사례가 이미 우리도 하고 있었던 것임을 기억할 필요가 있다. 4차 산업혁명에 대한 대응이라고 해서 새로운 사업 모델을 만들어 내야 한다고 생각하면, 이미 4차 산업혁명의 패러다임과는 거리가 멀다. 이 패러다임이 초연결성과 초지능화의 속성을 갖는 점을 감안하여, 기존의 사례로부터 최적의 사업 모델을 찾는 것이 오히려 적절할 수 있다. 
그럼에도 불구하고 4 차 산업혁명의 담론을 국제개발협력 분야에서 검토하는 것은 중요한 의미를 지닌다. 이것은 개발협력을 철학적 - 역사적 - 정치적 또는 경제적 관점이 아닌, 기술적 관점에서 접근하는 것이기 때문이다. SDGs도 지속 가능한 발전을 위해서는 과학기술 혁신이 중요한 이행 수단이 되어야 한다는 메시지를 전달하고 있음을 감안할 때, 향후 기술변화로 인한 사회 변동의 관점에서 개발협력에 관한 여러 논의가 이루어질 필요가 있다.

앞서 분석한 내용들로부터 4 차 산업혁명의 시대에 국제개발협력 종사자들과 전문 기관들이 염두에 두어야 할 사항들을 몇 가지 도출할 수 있다. 첫째, 기관 자체의 역량 강화다. $\mathrm{DFID}$ 와 $\mathrm{USAID}$ 의 전략에서 드러나는 것처럼 개발도상국의 역량 강화를 지원하는 것 못지않게, 전문 기관 또는 개개인이 데이터 및 디지털 기술 활용 역량을 갖추는 것은 중요하다. 개발협력 기관의 경우라면, 추진되고 있는 사업, 네트워크, 학술 활동 등을 통해 어떠한 데이터를 만들어 내고 있는지, 그리고 그러한 데이터를 어떻게 관리하고 있는지 냉정하게 검토할 필요가 있다. 그리고 검토 결과를 바탕으로 향후에 어떤 데이터를 생산하는 기관이 되고 싶은지를 결정할 필요가 있다. 가치 있는 데이터를 보유하는 것은 초연결성과 초지능화의 사회에서 갖춰야 할 필수 요소이기 때문이다.

둘째, 데이터와 디지털을 가능한 모든 활동에 주류화시키고, 타 기관과의 공조를 강화하는 것이다. 일부 사업을 가지고 개발도상국의 4차 산업혁명 또는 미래 기술에 대한 대응 역량을 높이는 것은 불가능하다. 개발협력 기관에서 프로그램을 기획할 때, 프로그램의 추진 과정에서 디지털 기술의 활용을 적극적으로 고려할 필요가 있다. 또한 사업을 추진하는 과정에서 의미 있는 데이터가 축적될 수 있도록, 데이터 관점에서 사업을 기획할 필요가 있다. 또 다양한 기술 적용 솔루션을 개발하고, 관련 기관들과 성과를 공유할 필요가 있다. 이를 통해 경험 축적을 위한 시간을 단축시킬 수 있고, 효과적인 스케일 업(scale up)을 달성할 수 있기 때문이다.

마지막으로, 데이터 및 디지털 기술의 적용이 수원국 사회에 미칠 수 있는 부정적 영향에 대해 지속적으로 논의하여야 한다. 개발도상국이 선진국들과 같은 속도로 미래에 대한 대응 전략을 수립하기는 어렵다. 여기에는 누군가의 지원이 필요하며, 그것은 선진국에 소속되어 있으나 개발도상국의 발전을 위해 일을 하는 국제개발협력 기관에게 부여된 책임일 것이다. 데이터 주권에 관한 논의가 하나의 사례가 될 수 있다. 선진국이 개발도상국에 데이터 기반을 구축하는 것은 중요하고 필요한 일일 것이나, 이를 통해 개발도상국의 데이터를 독점적으로 관리하고 활용하게 된다면 이는 오히려 부정적인 결과를 초래할 수 있다. 이러한 부정적인 상황들은 사전에 설정된 규칙 등을 통해 예방되어야 한다.

국제개발협력은 공여자의 전적인 경제적 이익 추구와, 인도주의의 완전한 실현이라는 양극단 
사이의 한 지점에서 이루어진다고 할 수 있다. 데이터와 디지털로 설명될 수 있는 4 차 산업혁명의 시대에는 보다 빠르고 효율적인 방법으로 개발도상국의 문제에 대한 해결 방안을 찾을 수 있다. 이것은 미래 기술의 변화로부터 오는 밝은 측면이다. 동시에 기술 혁신의 속도가 빨라지고 그 파급효과가 커짐에 따라, 선진국과 개발도상국 간의 기술격차가 더욱 커질 우려가 있으며, 개발도상국의 선진국 종속 현상도 더욱 심화될 가능성이 있다. 이것은 미래 기술의 변화로부터 파생되는 어두운 면이라고 할 수 있다. 국제개발협력에서 기술 발전의 긍정적인 효과를 극대화 시키고 부작용은 최소화시키기 위해 지속적인 논의와 다양한 시도가 요구된다.

\section{제I 장}




\section{〈참고 문헌〉}

김상훈. 2017. “4차 산업혁명: 주요 개념과 사례” 『산업경제분석』. 2017년 5월호. 세종: 산업연구원.

김영목. “제4차 산업혁명과 한국의 국제개발협력” 「매일경제」(2016.01.29. 보도기사). 김진하. 2016. “제4차 산업혁명 시대, 미래사회 변화에 대한 전략적 대응 방안 모색”.

『Inside and Insight』vol. 24. 서울: 한국과학기술기획평가원. 대통령직속 4차산업혁명위원회. 2017. 『4차 산업혁명 해외 정책 자료집. 존 하겔(John Hagel). 2016. 『디지털 혁명시대 격변의 9가지 패턴 - 유니콘, 블랙스완,

기하급수 기술의 세계에서 격변적 전략을 예상하기₫. 딜로이트 안진경영연구원 역. 서울: 딜로이트 안진회계법인.

배용진. 2017. “관(官)이 낳은 버블 한국에만 있는 4차 산업혁명”. 『주간조선』2509호.

서울: 조선일보.

안현실. “4차 산업혁명을 파는 장사꾼들”. 「한국경제 오피니언」(2016.11.18.보도기사). 윤유리. 2017a. “제4차 산업혁명과 국제개발협력의 미래” 『개발과 이슈』 제29호. 성남: 한국국제협력단.

2017b. "UN 고위급정치포럼(HLPF)의 SDGs 이행과정 검토 II". 『개발과 이슈』 제39호. 성남: 한국국제협력단.

이근. 2005. 『기술경제학의 다양한 접근을 종합한 기술추격론의 재구성』. 서울: 과학기술 정책연구원.

이상급. 2016. "KOICA의 과학기술혁신 중장기 전략: 현황과 과제”. 『국제개발협력』 2016년 제 4 호. 성남: 한국국제협력단.

이정동. 2017. 『축적의 길』. 서울: 지식노마드.

이정원·문형돈. 2018. "4차 산업혁명 시대, 우리의 인공지능 현황” 『IITP-정책브리프. 2018-5호』. 대전: 정보통신기술진흥센터.

이효정. 2014. “미국의 농업부문 ODA 현황과 사례” 『세계농업』 제166호 서울: 한국농촌 경제연구원.

임한나. 2018. "디지털 시대의 개발도상국을 위한 금융포용”. 『Sectoral Issue Report』 vol.8. 성남: 한국국제협력단.

정민. 2016. “2016년 다보스 포럼의 주요 내용과 시사점 - '4차 산업 혁명', 글로벌 성장 원동력으로”.『현안과 과제』16-2호. 서울: 현대경제연구원. 
정보통신기술진흥센터. 2016. “주요 선진국의 제 4 차 산업혁명 정책동향 - 미국, 독일,

일본, 중국” 『해외 ICT R\&D 정책동향』 2016-04호. 서울: 정보통신기술진흥센터. 최병삼·양희태·이제영. 2017. “제4차 산업혁명의 도전과 국가전략의 주요 의제”. 『STEPI

Insight』 제215호. 세종: 과학기술정책연구원.

테크노베이션파트너스. 2016. 『4차 산업혁명 정의 및 거시적 관점의 대응방안 연구』.

세종: 산업통상자원부.

DFID. 2012. “Department for International Development DIGITAL STRATEGY 2012-2015”. London: Department for International Development.

. 2018. "Digital Strategy 2018-2020: Doing Development in a Digital

World”. London: Department for International Development.

TSO. 2009. "Digital Britain: Final Report”. Norwich: The Stationery Office. USAID. 2017. “2017 Digital Download” (온라인 브로슈어). Washington D.C: United States Agency for International Development, available at https://www.usaid.gov/digital-development/2017-DigitalDownload (접속 일: 2018.5.27.)

Washington D.C: United States Agency for International Development, available at https:/www.usaid.gov/documents/15396/2017-digital-development-awards (접속일: 2018.5.27.)

WEF. 2016. "The Future of Jobs: Employment, Skills and Workforce Strategy for the Fourth Industrial Revolution”. Geneva: World Economic Forum.

대통령직속 4차산업혁명위원회: www.4th-ir.go.kr (접속일 : 2018.5.27.)

미국 Feed the Future 이니셔티브: https://www.usaid.gov/sustaining-ftfprogress (접속일: 2018. 5.27.)

세계경제포럼: www.weforum.org (접속일: 2018.5.27.) 